Archived version from NCDOCKS Institutional Repository http://libres.uncg.edu/ir/asu/

Pine, J. C., Marx, B. D., Levitan, M. L., \& Wilkins, D. (2003). Comprehensive assessment of hurricane shelters: lessons from Hurricane Georges. Natural Hazards Review, 4(4), 197-205. (ISSN: 1527-6988) Published by Forest Products Society. The version of the record is available open access http://0search.ebscohost.com.wncln.wncln.org/login.aspx?direct=true\&db=eih\&AN=11092491\&site=ehost-live

\title{
Comprehensive Assessment of Hurricane Shelters: Lessons from Hurricane Georges
}

\author{
John C. Pine; Brian D. Marx; \\ Marc L. Levitan; and Daniel Wilkins
}

\begin{abstract}
Gulf of Mexico states concerned with the potential adverse impact of a hurricane, participated in a joint effort to systematically evaluate the structural integrity of shelters to be opened in the event of a hurricane. The University of Florida School of Building Construction under contract by the Florida Office of Emergency Management, prepared a detailed hurricane shelter site evaluation worksheet, guide, and summary form to be used in an assessment of hurricane disaster shelters. The worksheet and summary form were established with consideration of shelter requirements established by the American Red Cross. An assessment of hurricane shelters was completed in 1998 in the southern half of Louisiana under contract with the Louisiana Office of Emergency Preparedness using the Florida shelter assessment materials prior to Hurricane Georges. Using data from this assessment, a statistical analysis was performed comparing the shelters used and not used in Hurricane Georges in Louisiana. The analysis was completed by both individual hazard criterion and for a marginal composite criterion, to test whether the proportions of response profiles (preferred, acceptable, and marginal) varied significantly across the used and unused shelters. The response profiles were particularly significant in the "building construction" category, with $74 \%$ (399\%) in the preferred category for the used (unused) shelters. There was also considerable dissatisfaction with the "wind design," "exterior wall design," and "interior safe space" with less than $5 \%$ in the preferred categories for both the used and unused shelters.
\end{abstract}

\section{Introduction}


Possibly the largest hurricane evacuation of a major city in the United States was initiated as a result of the potential threat to the New Orleans metropolitan area from Hurricane Georges beginning September 24, 1998. Hurricane Georges formed in the eastern Atlantic on September 15, 1998; by the next day, the system was upgraded to a tropical storm. Using satellite imagery, the National Weather Service determined that the storm had developed an eye and upgraded it to a hurricane on September 17, 1999. The storm moved west to northwest at $8.94 \mathrm{~m} / \mathrm{s}(20 \mathrm{~m} / \mathrm{h})$, reaching a Category 4 rating with peak winds of $67.056 \mathrm{~m} / \mathrm{s}(150$ $\mathrm{m} / \mathrm{h}$ ). Louisiana emergency management officials at the state and local level examined the projected path of the storm and determined that the impact of the storm on the people of New Orleans could be devastating. Emergency management officials from the coastal parishes of Plaquemine and St. Bernard explained the potential impact of the storm to citizens and ordered evacuations; City of New Orleans emergency management officials recommended that residents and visitors evacuate the city.

In 1997, prior to Hurricane Georges, Officials of the Louisiana Office of Emergency Preparedness (LOEP) determined that local jurisdictions were unprepared to shelter residents safely in a hurricane and initiated a shelter evaluation effort. The assessment was undertaken in a cooperative project with other Gulf of Mexico states in the United States. Financial support was provided to states by the Federal Emergency Management Agency (FEMA). Louisiana received approximately $\$ 100,000$ to complete this assessment. A comprehensive hurricane shelter assessment form and guide were developed for the Gulf states as a part of this multistate cooperative effort. As it turned out, Hurricane Georges provided a real world test for the shelter assessment process.

This paper provides an overview of the shelter assessment process and the criteria used to determine the suitability of using structures as shelters in a hurricane. Examples of shelters evaluated are provided to illustrate some of the criteria used in the assessment. The paper also examines whether the shelters evaluated and used in Hurricane Georges differed from those which were evaluated and not used by local officials in Hurricane Georges. 


\section{Storm and the Order to Evacuate}

Concerns over the path of Hurricane Georges' and its potent mix of strong winds and heavy rainfall caused Louisiana officials to order evacuations. The New Orleans Times Picayune reported that "whether mandatory or voluntary, the message to 1.4 million New Orleans area residents was the same: Get out." While many noted the irony of recommending a hurricane evacuation on a beautiful Saturday afternoon, New Orleans Mayor, Marc Morial, warned the city's residents to not take the storm lightly. "Our recommendation to people is to go," Morial said. "We are in a state of emergency; people shouldn't be lulled into comfort because the sun is out." With these warnings, residents piled onto the Interstate Highways leaving the metropolitan New Orleans area. Mayor Morial encouraged residents "to proceed with calm and with patience" (Bell 1998).

The eye of Hurricane Georges made landfall early on the morning of September 27, 1998 near Biloxi, Mississippi. The National Hurricane Center reported that Hurricane Georges had maximum sustained winds of $46.939 \mathrm{~m} / \mathrm{s}(105 \mathrm{~m} / \mathrm{h})$ with gusts as high as $55.88 \mathrm{~m} / \mathrm{s}(125 \mathrm{~m} / \mathrm{h})$. Georges made its landfall as a Category 2 hurricane according to the Saffir-Simpson Hurricane Scale and then moved slowly west-northwest leaving large amounts of rain along the Gulf Coast-more than $0.381 \mathrm{~m}$ (15 in.) in some areas. Louisiana and especially city of New Orleans officials were thankful that the storm did not continue on its earlier northwestern path, which would have been the worse case scenario for storm surge and water inundation for the city. New Orleans was spared a Category 4 storm with winds of up to $67.056 \mathrm{~m} / \mathrm{s}(150 \mathrm{~m} / \mathrm{h})$.

\section{Hurricane Shelter Assessment Process}

The shelter assessment program was a cooperative effort by the State of Louisiana Office of Emergency Management and parish emergency management agencies as well as other Gulf Coast state emergency management agencies. Preparation for the Hurricane shelter assessment was initiated well before Hurricane Georges hit the coast of Mississippi in September 1998. The assessment process was completed in Louisiana between May and August of 1998. The state agencies had approached FEMA requesting financial support for the development of comprehensive evaluation criteria for use in selecting hurricane shelter locations. Funding was provided in 1997 to Gulf Coast states to support the 
development and use of hurricane shelter assessment guidelines. The State of Florida, in cooperation with University of Florida's School of Building Construction, prepared a detailed hurricane shelter site evaluation worksheet and guide (1997). The worksheet reflected requirements of the American Red Cross Guidelines for Mass Care and Guidelines for Hurricane Evacuation Shelter Selection $(1987,1992)$. The site evaluation worksheet is a 30 page document divided into major sections to reflect the major structural risks associated with building failure and injury to persons and property from hurricanes. The worksheet includes the following categories: Storm surge inundation; rainfall flooding/ dam considerations; hazardous material and nuclear power plant considerations; lay down hazard exposure; wind and debris exposure; wind design verification; construction type/load path verification; building condition/wind damage history; exterior wall construction; fenestrations/window protection; roof construction and slope; roof open span; interior safe space; and life safety and emergency power. Two sections of the form, including exterior wall construction and fenestrations/window protection, are in the Appendix. These sections of the detailed assessment provide an example of the scope of the shelter evaluation process and the level of detail of the assessment process.

In addition to the comprehensive shelter evaluation worksheet, a users manual was prepared for those completing the site assessments as well as state and local officials whose buildings would be subject to the assessment process. The manual includes background information on the hurricanes, wind structure interaction, and the effects of storm surge and flooding from rainfall. The manual provides suggestions for local officials in coordinating the assessment of shelters in a community (University of Florida 1997).

The LOEP had created a shelter task force composed of local emergency management officials following Hurricane Andrew in 1992. This task force worked with state emergency management staff and faculty from Louisiana State University (LSU) to determine how the shelter assessment process should proceed. Between January and March 1998, a series of "hurricane shelter selection" workshops were conducted by LSU faculty for state and local emergency management officials. The workshops were to introduce local officials to the state's hurricane shelter assessment process and selection criteria.

The Louisiana shelter task force, along with staff from LOEP and LSU, analyzed the wind and storm surge risks associated with 
Gulf of Mexico hurricanes. They determined that parishes (counties) in the northern half of the state were less vulnerable to the storm surge and winds associated with hurricanes than parishes in the southern half of the state. As a result, the assessment of hurricane shelters in the state was to target parishes in the southern half of Louisiana. An assessment of shelters in the northern half of the state would also be initiated if funding were provided in the future.

Parishes in the southern half of the state were categorized as at risk. because they were subject potentially to the heaviest winds and storm surge from Gulf of Mexico hurricanes. The LOEP encouraged these parishes (34) in the at risk area to participate in the shelter assessment effort. According to Louisiana's emergency response plan, an evacuation would be ordered in at risk parishes in a Category 4 hurricane if the parish was in the projected path of the storm (Louisiana Office of Emergency Preparedness 1996). Local shelters could be opened in the at risk parishes if the structure met or exceeded the hurricane shelter selection criteria. Parishes outside the at risk zone were considered host parishes. In the state emergency operations plan, the host would be asked to open shelters for evacuees from the at risk areas of the state. The host parishes were considered to be outside the most vulnerable areas subject to the high winds and storm surge of a hurricane. Fig. 1 shows the at risk parishes that were the target for this shelter assessment process.

Following the hurricane shelter selection workshops, local emergency management officials in the at risk areas were asked to prepare a list of potential hurricane shelters in their jurisdictions. The hurricane shelter sites identified by local officials were scheduled for a detailed evaluation by a team of LSU faculty, staff, and students with a background in civil engineering. A total of 188 local shelters were included in the detailed assessment process conducted between May and August 1998. Additional shelters were also examined at the request of local officials, but were not subjected to the detailed assessment process because of obvious structural limitations of the site. Most of the sites excluded from the detailed assessment were one-story nonreinforced concrete block structures with large windows. The detailed assessment of a shelter took approximately $3 \mathrm{~h}$ at an average cost of $\$ 450$ per shelter.

In addition to the detailed shelter evaluation form, a second form, shelter summary compliance form, was completed by local emergency management official in cooperation with the site shelter 
site evaluation team. The shelter summary compliance form is based on the overall format of the detailed shelter assessment form and provides local officials with a decision making process on the use of the site as a hurricane shelter.

Fig. 1. Study area

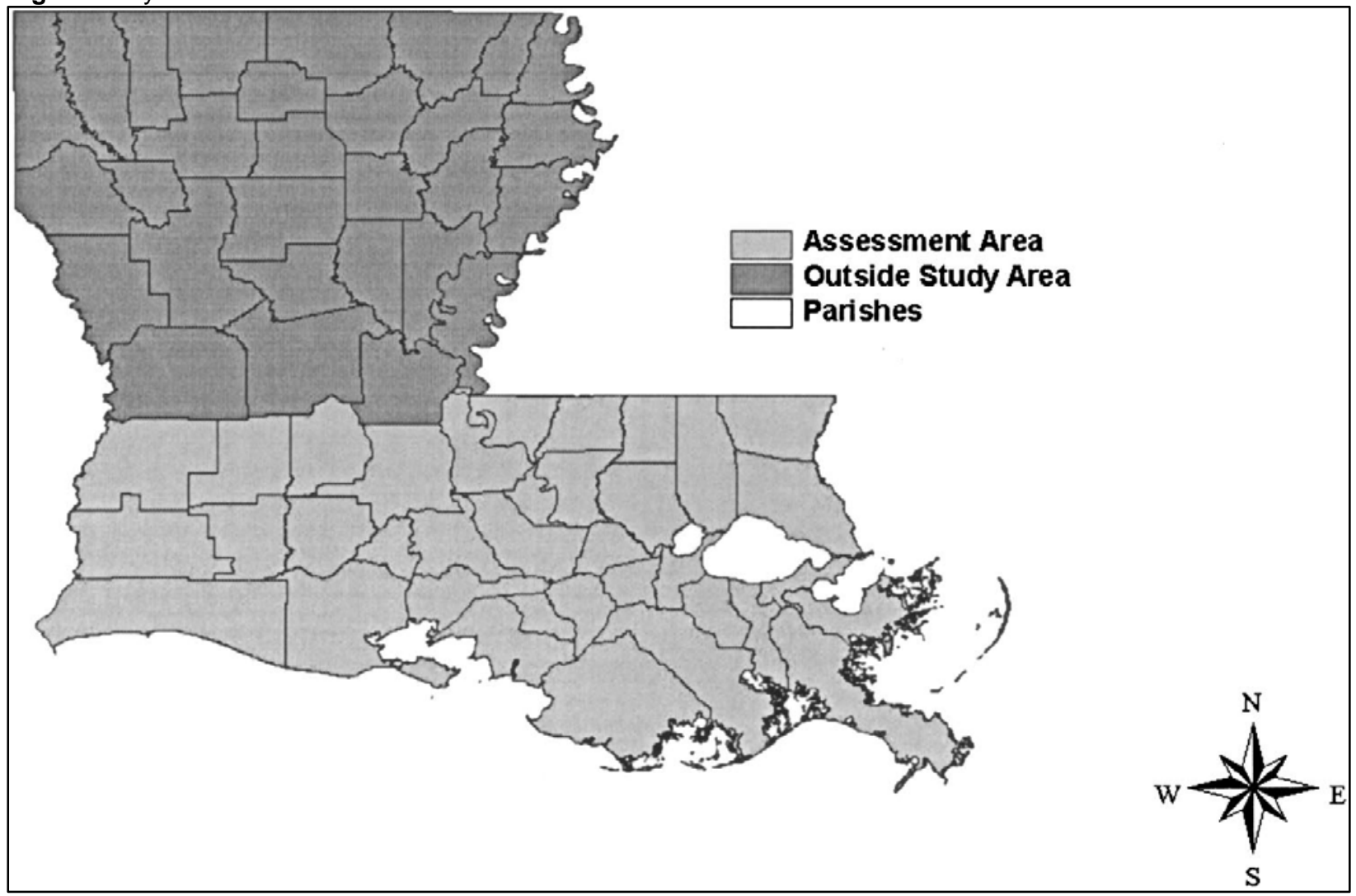

The shelter summary compliance form follows the major sections of the detailed assessment form and requires the local official to rate the shelter as preferred, acceptable, or marginal on each of the fifteen sections. Numerous technical factors were considered in determining the rating for any one of the major evaluation components. The preferred, acceptable, and marginal ratings were adapted from terms initially developed by Florida emergency management officials. A preferred rating is one in which the site exceeds the evaluation criteria; an acceptable rating indicates that the site meets the evaluation criteria; and the marginal rating is the least acceptable category. The marginal rating suggests that there are problems with the site that may be corrected. The rating could also reflect that while some parts of the site are not suitable as a hurricane shelter other areas within the site are appropriate for use as a hurricane shelter.

The shelter summary compliance form was designed to be completed by local emergency management officials with the assistance 
of the LSU evaluation team members. However, local parish emergency managers asked that the form be completed by the LSU assessment team members.

A total 26 out of 34 at risk parishes participated in the hurricane shelter assessment project. The total number of shelters evaluated in these parishes was 188 sites. As a part of the shelter assessment process, a report was provided to each parish summarizing the structural evaluation of each hurricane shelter. The parish report included maps showing the relative location of shelters to flood zones, sites with hazardous materials, and storm surge areas to Category 4 storms. Local officials used the shelter assessment report along with the shelter summary compliance form in their final decision for designating which shelters would be used in the event of a hurricane.

It should be noted that not all of the at risk parishes participated in the shelter assessment process. Eight of the parishes considered to be in the at risk area, chose neither to participate in the Hurricane Shelter Assessment Workshops nor identify shelters for an evaluation. Although the LOEP provides some funding for local jurisdictions to support local emergency management functions, the receipt of this funding was not based on participation in the shelter assessment process. Since the LOEP does not completely fund local emergency management activities, the nature and extent of local involvement in emergency services varies greatly throughout the state. The six parishes that chose not to participate in the shelter assessment process either determined that they would not open shelters in the event of a hurricane or determined independently that their shelters were satisfactory and further evaluation was unnecessary. As it turned out, these parishes opened shelters in Hurricane Georges even though they had not participated in the shelter assessment process.

The evaluation of shelters in the 26 parishes was an attempt to identify the best structures for use as shelters in the event of a hurricane. Since the decision to open and use shelters is a local decision in Louisiana, it was critical that local officials have sufficient information to base their decisions. Further, the shelter assessment process was intended to be carried out in a systematic and consistent manner throughout the at risk parishes and ensure that shelters opened in the event of a hurricane would be safe for those seeking refuge. 


\section{Characteristics of Shelters Opened in Hurricane Georges}

Hurricane Georges provided an opportunity to evaluate the results of Louisiana's shelter assessment process. Local emergency management officials made decisions using the results of the assessments to open or not to open hurricane shelters. This analysis is an attempt to compare the characteristics of the hurricane shelters that were opened with those that were not opened in parishes that participated in the hurricane shelter assessment process. The central question was whether the shelters used were different from those not used in Hurricane Georges.

This analysis is based on the shelter assessment categories in the shelter summary compliance form. Of the fifteen categories in this form, eleven are associated with the structural characteristics of the building and the capacity of the site to withstand the extensive winds associated with a hurricane. Four of the categories are not associated with the structural integrity of the site and are not used as a part of this analysis.

A total of 88 shelters in 26 parishes were opened in Louisiana for Hurricane Georges. Of these shelters, a total of 29 were opened in 8 of the at risk parishes that had participated in the hurricane shelter assessment process. The summary compliance forms completed by the at risk parishes form the basis for this analysis.

Shelters were opened in Hurricane Georges in seven at risk parishes that did not participate in the hurricane shelter assessment process. A total of 22 shelters were opened in these parishes. Since they did not participate in the shelter assessment process prior to Hurricane Georges, no data were available for use in this analysis. Finally, 11 parishes outside the at risk areas of the state opened a total of 34 shelters in Hurricane Georges. These eleven parishes were host parishes under the LOEP emergency response plan and were not a part of the hurricane shelter assessment process. No data on the shelters in the host parishes are available for use in this analysis.

A total of 29 shelters were opened in Hurricane Georges by parishes participating in the hurricane shelter assessment process. Of these shelters, 19 had been evaluated and 10 had not been evaluated. These parishes also made the decision not to use 44 shelters that were evaluated in the hurricane shelters assessment process. This analysis compares the ratings for the 19 shelters used and the 44 shelters not used in Hurricane Georges. The 
ratings from the shelter survey compliance form provides the basis for this analysis.

\section{Shelter Site Comparison Categories}

For three categories, state and local officials agreed that hurricane shelters should be located outside FEMA 100 year flood zones, outside Category 4 Storm Surge areas as calculated by computer simulations of Gulf storms, and extremely hazardous or radioactive materials were not stored or used on site or within a close distance of the shelter. Since all the sites met these three criteria, they were not included in our comparison of shelters used and not used in Hurricane Georges. A fourth category involving the availability of an alternate power source or generator on site was not included in our analysis since only one of the sites had an alternative power supply. The remaining 11 categories reflect the structural characteristics of the shelter and formed the basis of our analysis. A brief description of each of the eleven structural categories and the ratings associated with them follows.

\section{Lay Down Hazards}

The lay down hazard exposure describes any type of object which is close enough that if it fell over, at a right angle to it's base, it would strike the structure with enough force to breach the buildings envelope. These would be trees, electrical towers or trees lined along the road falling, and limiting access to the structure. Characteristics of a preferred shelter would be one with no large trees or structures within a lay-down vicinity, and at least one access route, which would not be obstructed by lay-down hazards. Trees or structures which are not large enough to cause structural damage or lay outside the lay-down range would rule the shelter acceptable. Lay-down hazards which are within lay-down range and are capable of inflicting a significant breach of the buildings envelope would result in a rating of marginal. Trees and power line towers were annotated as lay-down hazards in these shelters. Fig. 2 provides a good illustration of a site that has few lay-down hazards. The school building is not exposed directly to lay-down hazards.

Fig. 2. Sample school shelter No. 1 


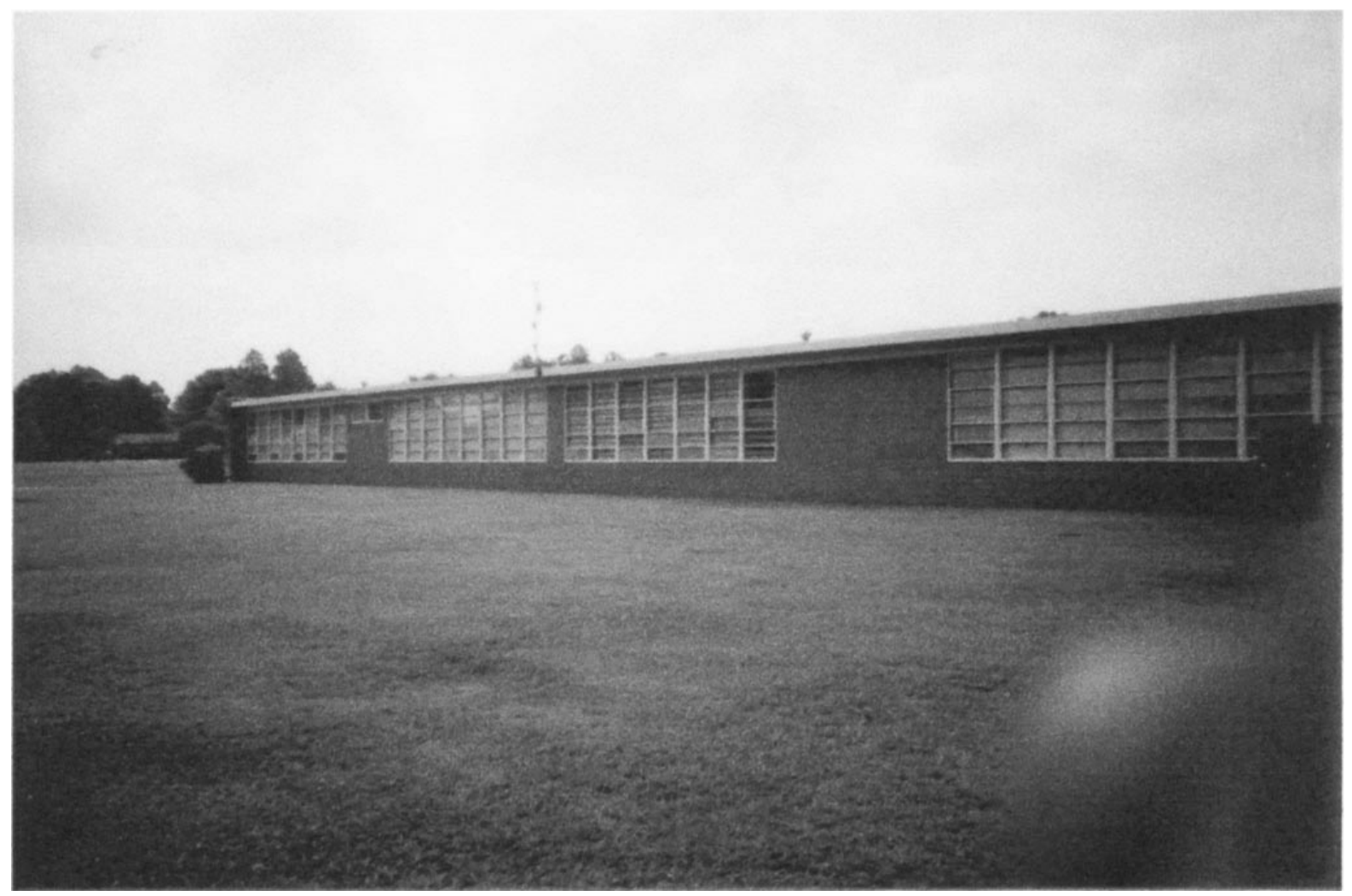

\section{Wind and Debris Exposure}

The second exposure criteria evaluates the building vulnerability to wind and debris. Debris potentially could penetrate walls and windows or otherwise cause damage to the facility. Debris is classified as large, rollover, and lofted heavy. Large debris is described as objects which weigh between 6-20 pounds, such as, building materials, framing studs, plywood sheets, and potted plants. Rollover debris is described as unanchored or inadequately anchored objects that may become airborne pushed or rolled along the ground surface by hurricane winds. Trailers or vehicles are examples of rollover debris. Lofted heavy debris is an object that if wind borne would cause the structure to fail catastrophically. Portable buildings, poorly maintained homes, gravel from rooftops and parking lots are cumulatively problem areas with these shelters. A preferred shelter is required to have a sheltered exposure and should have no large unanchored objects, which are subject to rollover or potential heavy lofted debris within 100 feet. In addition, there should be no large or small wind borne debris sources within three hundred feet. The structure would be acceptable if all of the above criteria are met except that it had 
limited wind exposure and marginal if it had an unsheltered exposure. Fig. 2 has no unanchored objects in the area. The covered light metal walkway in Fig. 3 would be vulnerable to heavy winds and thus present a debris exposure and danger to the site. Although such covered walkways provide shelter in rain storms, they provide exposures in heavy winds such as a hurricane.

\section{Wind Design Verification}

Wind design verification describes a requirement for certification by a structural engineer indicating that a building conforms to ASCE 7-88. This indicates the building is in compliance with the best wind design standard currently available. At the time that the comprehensive survey form was prepared (October 1997) ASCE 7-88 or ANSI A58 (1982) were some of the most stringent wind load requirements available, especially with respect to wind effects on components and cladding. A preferred structure conforms to ASCE 7-88 as well as meets the wind design criteria of ANSI A58 (1982). The structure is acceptable if the wind design is in accordance with the Standard Building Code or other model codes, and no apparent design/construction flaw that could otherwise impact wind resistance. A structure is deemed marginal if it was built prior to 1960, lacks good wind engineering design and construction, or is designed to wind speeds less than a Category 1 hurricane $(42.02 \mathrm{~m} / \mathrm{s})$.

Fig. 3. Sample school shelter No. 2

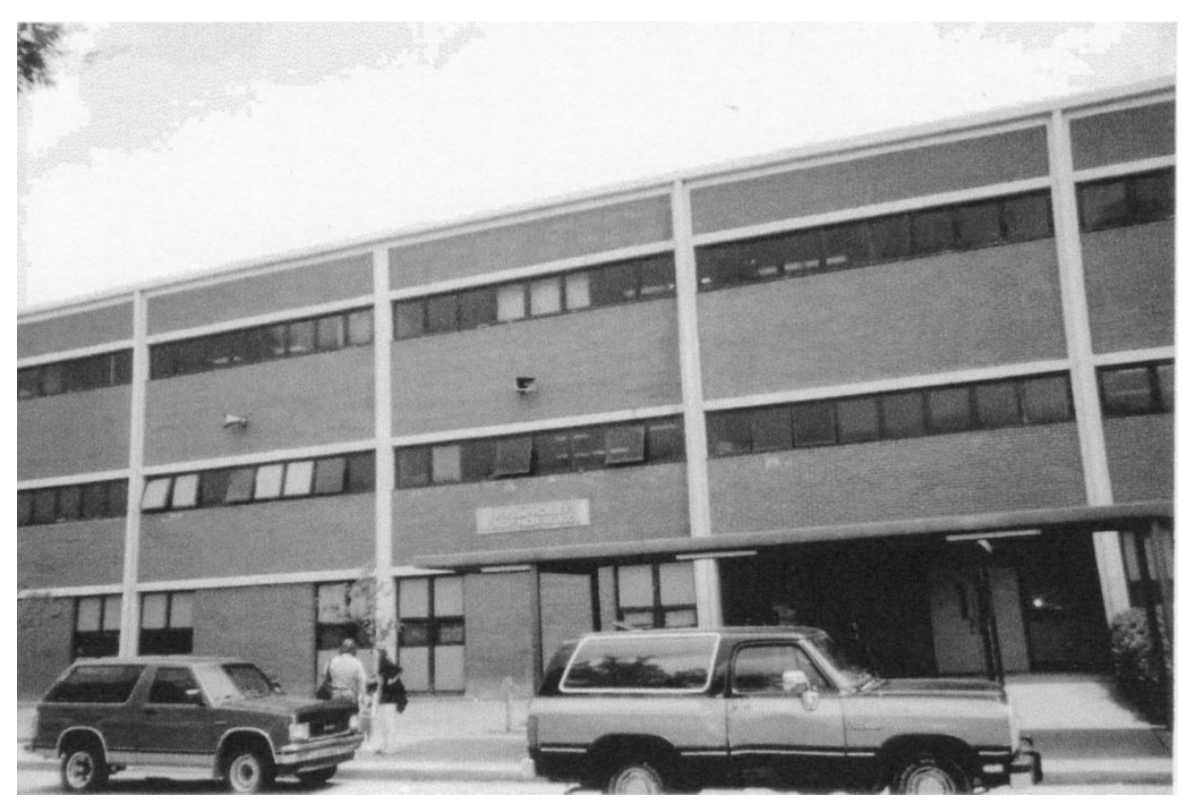

Construction Type 
Construction type and load-path verification are some of the most important aspects of the evaluation process. This is the identification process of a definable and continuous load path for resistance to wind-induced loads. Structures were checked for reinforced concrete load bearing walls, hurricane straps attached to the roof, and continuous load path. A preferred structure has a heavy steel or reinforced concrete frame, a clearly defined continuous load path from roof deck to foundation. All connections were required to withstand vertical uplift and shear forces. An acceptable structure will have masonry exterior walls with partial reinforcement or buildings constructed of wood or metal stud wall systems that meet SSTD 10-93 (or more recent versions). Fig. 3 provides an illustration of reinforced concrete load bearing walls that are preferred in hurricane shelters. Marginal structures are buildings with no observable or verifiable continuous load path from roof deck to foundation to resist wind uplift forces. Fig. 2 is a common building construction type found in the study with no use of reinforced concrete load bearing walls.

\section{Building Construction}

Building construction verified the overall condition of the building. The building was evaluated for deterioration, cracks in the masonry structure, and present or previous wind damage to the structure. The majority of the buildings were well maintained and only showed minor deterioration. A preferred building is in good condition with no apparent signs of deterioration and is approximately as sound as it was when new. An acceptable building has minor deterioration, which does not appear to impact wind resistance. A marginal building shows major deterioration and the substructure may impact wind resistance. The sites shown in both

Figs. 2 and 3 reflect well maintained structures with limited deterioration.

\section{Exterior Wall Construction}

The exterior wall construction verifies the ability of the exterior wall to resist wind loads and wind borne debris impacts. The exterior walls of the preferred structures were constructed of fully reinforced masonry or concrete wall systems and less than five percent of any wall face's area comprised a soft-spot area. An acceptable structure has partially reinforced exterior walls or similar wind resistance characteristics to partially reinforced masonry. A marginal structure has glass panel facade walls, light 
metal cladding, or other lightweight panels.

\section{Fenestration}

Fenestrations and window protection consider unshuttered or unprotected windows, which can be a soft spot in a buildings envelope.

Preferred structures had exterior walls or a protection system that would comply with, or exceed, the performance standards/protocols of SSTD 12-94 or local building codes. An acceptable building has other types of fenestration protective systems that are not certified to meet standards. A marginal building has unprotected fenestrations that lead into shelter areas. Fig. 2 shows that the site has large windows that could expose occupants to external hazards. Fig. 3 has much smaller window treatment on the second and third floors offering much better protection from flying objects that could pose harm to the shelter site and its occupants. The large windows shown on the first floor of Fig. 3 were for the office of the school. Most of the windows on the first floor were similar to the small windows on the second and third floors of this school.

\section{Roof Construction}

Roof construction and roof slope were inspected for construction, anchoring, overhang, and equipment mounted to roofs. Preferred structures have roofs of heavy construction such as structural concrete with a 4 in. minimum thickness deck, moderate weight deck with a roof slope of $30^{\circ}$ or greater, less than a $1 \mathrm{ft}$ overhang, and no unanchored appendages present. An acceptable building has a flat and/or lightweight roof system with engineered mechanical connection (bolts, welds, etc.) to support structures below and less than a $1 \mathrm{ft}$ overhang. A marginal structure has a flat lightweight roof system with a gravity connection to support structures below and has greater than a $1 \mathrm{ft}$ overhang. Roofs of heavy construction with no overhang were preferred. Fig. 2 shows a building with a flat lightweight roof system with a gravity connection to the structure below. This site also has an overhang of greater than $1 \mathrm{ft}$. Fig. 3 shows a much more desirable roof construction type of structural concrete and no overhang.

\section{Roof Open Spans}


Roof open spans were inspected for unsupported spans no longer than $40 \mathrm{ft}$. Large open areas, such as auditoriums or cafeterias, were most likely not to meet these criteria. These areas can be used for staging prior to the storm or after the storm but not for sheltering during the storm due to the low protection capability. Preferred structures will have less than $40 \mathrm{ft}$ distance between vertical support elements (bearing walls and/or columns) of the roof. An acceptable building has a light- or medium-weight roof system with a moderate to steep roof slope with fifty feet or less between roof spans. A marginal building has a flat or shallow slope, light-weight roof system with vertical supports greater than $40 \mathrm{ft}$ apart.

Table 1. Characteristics of Sheiters Evaluated in Hurricane Georges: Used and Not Used

\begin{tabular}{|c|c|c|c|c|c|c|}
\hline \multirow[b]{2}{*}{ Farard criteria } & \multicolumn{3}{|c|}{ Used } & \multicolumn{3}{|c|}{ Not moed } \\
\hline & Profented & Acceptable & Marginal & Prefersted & Accopable & Margingel \\
\hline Lay down hazards & 10 & 5 & 4 & 11 & 11 & 22 \\
\hline Debria axposure & 10 & 7 & 2 & 29 & 16 & 9 \\
\hline Wisd donign varification & 1 & 2 & 16 & 1 & 5 & 48 \\
\hline Conutruction type & 9 & 1 & 9 & 12 & 8 & 34 \\
\hline Building construction & 14 & 4 & 1 & 21 & 18 & 15 \\
\hline Exterior wall comatruction & 1 & 5 & 13 & 1 & 10 & 43 \\
\hline Fenestration & 0 & 7 & 12 & 2 & 10 & 43 \\
\hline Roof comstraction & 7 & 4 & 8 & 8 & 20 & 26 \\
\hline Roof open spans & 8 & 6 & 5 & 18 & 21 & 15 \\
\hline Roof drainage and ponding & 10 & 7 & 2 & 18 & 21 & 15 \\
\hline Interior safe space & 1 & 7 & 11 & 2 & 16 & 36 \\
\hline Emargency powar" & & & & & & \\
\hline
\end{tabular}

"Of the 19 siten, only con had emergancy power.

\section{Roof Drainage and Ponding}

The roofs were inspected for drainage and ponding. Signs of existing problems were evaluated. A preferred structure has no parapet walls that confine roof drainage and no evidence of ponding. An acceptable building has scuppers present in parapet walls and ponding is minimal. A marginal building has no scuppers present and significant evidence of ponding and/or roof damage due to excessive ponding depths that could lead to roof collapse. 
Interior safe spaces were inspected for reinforced walls and window protection. Problems noted during evaluations included nonreinforced masonry walls and exposure to unshuttered windows.

A preferred building has interior corridors/rooms with reinforced masonry walls and a definable, continuous load path must be present from the roof/ceiling to corridor foundation. Acceptable buildings have a partially reinforced masonry wall and concrete or metal/ceiling deck. Marginal buildings consist of corridors with nonreinforced masonry and/or unprotected fenestrations. Fig. 3 provides far better protection to those sheltered inside since the building has corridors with reinforced masonry walls. Fig. 2 provides corridors with nonreinforced masonry walls and indirect exposure to large unprotect windows.

Although all the elements of the assessment process were important, several criteria had the highest marginal rating in the survey. $50 \%$ of the shelters assessed either received the preferred or acceptable rating in the construction type and load verification categories. Although $50 \%$ of the shelters were marginal in these categories, it does not mean that shelters were unsafe. Either some modifications to the shelters were needed or only a portion of the building was suitable to be used as a shelter during a hurricane.

The exterior wall construction was considered marginal in $65 \%$ of the shelters evaluated. The use of light metal cladding or other light-weight panels made these structures less than desirable for use as shelters in high winds.

Finally, $45 \%$ of the structures evaluated received the marginal ratings in the "roof construction" type. This was an area of concern to the evaluation teams since the roof was flat with a gravity connection to the structures below. Further, these structures had an overhang of greater than one foot. As a result, the assessment teams concluded that these marginal sites not be used as shelters. The extended overhang and lack of sound connection between the roof and supporting structures make these sites less than desirable for use as a hurricane shelter.

\section{Statistical Results}

Statistical analyses were performed comparing the ratings of shelters used and not used in Hurricane Georges. The analyses were by individual hazard criterion and for a marginal composite criterion, 
to test whether or not the proportions of response profiles (preferred, acceptable, or marginal) varied significantly across the used and unused shelters. See Table 1.

A rather obvious finding was that the response profiles of the composite criterion margining over categories, was highly significant $(p<0.00001)$ across the two tables, based on the chi-square test for homogeneity. The significance was primarily due to the fact that approximately $34 \%$ were in the preferred category for used shelters, compared to $21 \%$ for unused shelters. Clearly, the shelters used had a higher overall rating when compared to those not used. Such a result evokes the question as to which of the specific criteria are most significant. Interestingly enough, among all of these factors using partial tables, only building construction was compellingly significant $(p<0.02)$ with approximately $74 \%$ in the preferred category with used shelters and only $39 \%$ for the unused shelters. Other more borderline significant factors (0.05 $<p<0.10)$ were lay down hazards, construction type, and roof construction. Although the rest of the factors were nonsignificant, i.e., the response profiles are not statistically different across usage tables, it is worth noting that the preferred category entered less than $5 \%$ of the time for wind design verification, exterior wall construction, and interior safe space. Thus, despite some homogeneity in response profiles, there is considerable dissatisfaction.

\section{Telephone Survey with Local Emergency Management Directors}

The emergency management directors who opened hurricane shelters and had been involved in the state's hurricane shelter assessment effort were contacted to clarify the decision making process used in opening hurricane shelters during Georges. Each local parish director noted that the best shelters as recommended during the shelter assessment effort were opened for Hurricane Georges. They explained that their determination as to which shelters were best suited for hurricanes was based on the comprehensive shelter assessment provided by the State Office of Emergency Preparedness and the LSU assessment teams. Shelters were either used or eliminated for consideration based on information provided as a part of the assessment process.

As to the shelters opened but not evaluated in the assessment effort, the local directors believed that the sites were as good or if not better than the sites inspected during the assessment effort. In Baton Rouge, New Orleans, Jefferson Parish, and East Feliciana 
Parish, shelters were opened to accommodate the large number of people seeking a safe location to ride out the storm.

When local emergency management directors were asked for their recommendations on using hurricane shelters, each suggested that additional shelter sites should be evaluated by engineering professionals and others knowledgeable of building design and construction. The shelter assessment effort was an extremely informative process and provided a basis for a determination of suitable hurricane shelter sites in their jurisdiction.

The directors also commented that their involvement in the shelter assessment effort was critical in understanding how to use the summary reports provided for each of the shelter sites. Knowledge of the structural characteristics of a shelter was considered critical in making effective decisions on using the site in a hurricane. Each parish director suggested that the assessment effort be continued to allow their parish to identify additional hurricane shelters.

It should be noted that the parishes which opened shelters and had participated in the shelter assessment process made the decision to open shelters that had not been evaluated (10). Of these shelters, nine were located in the New Orleans and Baton Rouge metropolitan areas. The tenth site was East Louisiana State Hospital in East Feliciana Parish. The city of Baton Rouge opened four shelters, the city of New Orleans three shelters, and Jefferson Parish in the Orleans metropolitan area opened two shelters not included in the state's hurricane shelter assessment effort.

A common characteristic of the ten shelters opened but subjected to the comprehensive shelter assessment process was their size. They were very large public facilities including the Louisiana State University Athletic Field House in Baton Rouge, the Louisiana Superdome and New Orleans Convention Center in New Orleans, and the New Orleans Metropolitan Airport in Jefferson Parish. Although these structures were not inspected as a part of the hurricane shelter assessment effort, the local directors who opened these shelters believed that these structures met the criteria and would withstand a hurricane. In the phone survey, the local directors stressed that the evaluation criteria was utilized to make the decision to activate hurricane shelters.

\section{Conclusions}


The hurricane shelter assessment process used by Louisiana parish emergency management agencies provided a systematic means of identifying the most appropriate locations for shelters in the state at risk zones. Although the process was initially completed for a portion of Louisiana, it does begin to address safe sheltering for the major population areas in the state.

The criteria used in the Louisiana shelter assessment was consistent with other Gulf Coast states. Emergency managers from other states may encourage their residents to evacuate and be assured that the shelters will be a safe refuge.

An effective hurricane sheltering system is based on the collaboration of many parties. Individuals evacuating one community are dependent on other local officials to select the safest shelters in these communities. Six of Louisiana's at risk parishes did not participate in the shelter assessment process and opened shelters (22) in Hurricane Georges. It is therefore critical that all parishes, especially those in the "at risk" areas of the state, participate in a shelter assessment program. It is unfortunate that some of the parishes did not participate in the hurricane shelter assessment process supported by both FEMA and LOEP.

Statistical analyses were performed comparing the shelters used and not used in Hurricane Georges, both by individual hazard criterion and for a marginal composite criterion, to test whether or not the proportions of response profiles (preferred, acceptable, and marginal) varied significantly across the used and unused shelters. The statistical analysis showed that there was a significant quantitative difference as measured by the assessment process in the overall building condition between those shelters used and not used. The response profiles were highly significantly different $(p<0.00001)$ across the used and unused shelters, based on the chi-square test for homogeneity. Partial tables demonstrate that most disparity is with the building construction category. Further, there was considerable dissatisfaction (less than $5 \%$ preferred) with wind design, exterior wall construction, and interior safe space.

Local emergency management directors who participated in the shelter assessment process opened hurricane shelters in Hurricane Georges with an understanding of the potential adverse impact that a Category 4 storm could have on structures. This appreciation of the damage that wind could cause made the shelter selection process more systematic. Decisions were based on 
established criteria, which were applied in parishes on a consistent basis.

Shelters opened for Hurricane Georges were considered by the local emergency management directors as the safest locations and the best available sites. The local directors were confident that the decision process was effective. All local jurisdictions opening shelters in a hurricane should participate in a comprehensive examination of the physical characteristics and location of a proposed site. Having an established hurricane shelter evaluation criteria applied throughout the state was a critical factor in the decision making process used by local emergency management officials.

Effective shelter selection is based on the confidence which local emergency management officials have in the decision making process. Accepted decision criteria applied on a consistent basis by a state's local governments forms the basis for effective decisions in a natural disaster. Where local officials understand the need for the consistent use of decision criteria, individual decisions by local officials are made with confidence that the emergency management system will function effectively. The involvement by local officials in applying the evaluation criteria to hurricane shelters in their jurisdiction can lead to more selective outcomes.

A limited telephone survey with local emergency management officials was conducted as a part of this study of shelters used and not used in parishes participating in the hurricane shelter assessment process. Further research should be undertaken to clarify critical shelter operational decisions by local emergency managers. At what point did they open the shelters? What do they consider to be the limitations of the shelters they used? How do they plan to address the limitations of the shelters?

\section{Acknowledgments}

Support for the Hurricane Shelter Assessment Study was provided by the Louisiana Office of Emergency Preparedness. The hard work of LSU Senior Civil Engineering students Todd Donmyer, Kevin Durbin, Ryan Hydrick, Bryan Jackson, Dale Leblanc, and Scott Swilley in performing the assessments is greatly appreciated. The authors also wish to acknowledge the cooperation and 
assistance of Louisiana state and parish emergency management

personnel for their participation in this research project.

\section{Appendix. Sections 9 and 10 from the Comprehensive Shelter Section Survey}

\begin{tabular}{|c|c|c|c|}
\hline \multicolumn{4}{|c|}{ SECTION 9 - EXTERIOR WALL CONSTRUCTION } \\
\hline YES & \multirow{2}{*}{\multicolumn{3}{|c|}{ 9.1 Are the exterior walls relatively wind and debris impact resistant? }} \\
\hline No & & & \\
\hline YES & \multirow[t]{2}{*}{9.1 .1} & \multirow{2}{*}{\multicolumn{2}{|c|}{$\begin{array}{l}\text { Does the building have un-reinforced masonry walls on its exterior? } \\
\square \text { Un-reinforced Masonry or } \quad \text { Rebar Spacing Unknown }\end{array}$}} \\
\hline No & & & \\
\hline \multirow[t]{6}{*}{ 9.1.1.1 } & \multicolumn{3}{|c|}{ If no, what is the Exterior Wall Construction type? (Check only one) } \\
\hline & $\begin{array}{c}\text { QReinforced } \\
\text { (Rebar @ }\end{array}$ & $\begin{array}{l}\text { d Masonry } \\
4 \mathrm{ft} \text {. centers or closer) }\end{array}$ & $\begin{array}{l}\text { Light Wood or Metal Stud } \\
\text { w/ } 1 / 2 \text { inch or thicker plywood }\end{array}$ \\
\hline & $\begin{array}{r}\text { Partial Reir } \\
\text { (Rebar @ } 8\end{array}$ & $\begin{array}{l}\text { inforced Masonry } \\
8 \mathrm{ft} \text {. centers to } 4 \mathrm{ft} \text {. centers) }\end{array}$ & $\begin{array}{l}\text { Light Wood or Metal Stud } \\
\text { w/ light non-plywood sheathing }\end{array}$ \\
\hline & $\begin{array}{l}\text { Partial Reir } \\
\text { (Four-bar }\end{array}$ & $\begin{array}{l}\text { inforced Masonry } \\
\text { Pilasters } 13 \text { feet on center or less) }\end{array}$ & $\begin{array}{l}\text { Large Panel Glass or other } \\
\text { Glazed Panel or Block System }\end{array}$ \\
\hline & $\begin{array}{l}\square \text { Reinforced } \\
\text { Concrete I }\end{array}$ & $\begin{array}{l}\text { d Concrete or Precast } \\
\text { Panels }\end{array}$ & $\begin{array}{l}\text { Metal Sheets or Panels or other } \\
\text { Light Architectural Panel Systems }\end{array}$ \\
\hline & O Other: & & \\
\hline
\end{tabular}

9.1.1.2 If Metal Sheets or Panels (e.g. PEMB structures), what is the gage of the metal sheets or panels?

$\square$ Thinner than 22 gage (26 gage, etc.) $\square 22$ gage or thicker (18, 16, etc.) $\square$ Not Applicable

9.1.2 Do the exterior walls have a brick or stone veneer (3 to 4 inches thick)? ? YES $\square$ NO

9.1.3 Do the exterior walls have an Exterior Insulating and Finish System (EIFS)? $\square$ YES $\square$ NO

9.1.4 Are there cantilevered walls (walls connected/supported at the base/foundation, but not at the roof) on the exterior of the building? $\quad$ YES NO

Describe:

9.1.5 Are there any other softspots noted in the building's exterior wall/roof?

Describe: 


\begin{tabular}{||l|l|l||}
\hline \hline \multicolumn{2}{||l}{ SECTION 10 - FENESTRATIONS/WINDOW PROTECTION } \\
\hline YES & & $\begin{array}{l}\text { 10.1 Are all the windows in the building adequately protected by shutters/protective } \\
\text { systems? }\end{array}$ \\
\hline NO & & \\
\hline
\end{tabular}

10.1.1 What is the percentage of Glass in the exterior walls ? $\square 0 \%$ to $1 \% \quad \square 2 \%$ to $5 \% \quad \square 6 \%+$

$\left(\_\right.$sq. ft. of glazing $\div \_$sq. ft. of exterior walls $\times 100=\ldots$ _ $)$

10.1.2 Are there "store-front", atrium, or clerestory sections of glazing in the exterior walls? $\square$ YES $\square$ NO

10.1.3 What type of glass is utilized in the exterior walls?

$\square$ Fully Tempered $\square$ Laminated Glass $\quad \square$ Other

10.1.4 Are all the windows in the exterior walls of the building shuttered/protected against windborne debris?

$\square$ YES $\square$ NO $\square$ Not Applicable

10.1.5 Has the shuttering/protective system used to protect the windows been certified to meet the windload and impact resistance standards in the Dade County version of the South Florida Building Code (Sections 2314.1, 2314.5, and 2315.1-2315.4), or SBC Standard SSTD 12-94?
口 YES
$\square$ NO
Not Applicable
$\square$ Unknown

10.1.6 If there is a shuttering/protective system in use but it is not certified to the standards in 10.1.5 above, is there documentation indicating the system was designed to transfer impact and wind loads to the building walls?
口 YES
$\square$ NO
Not Applicable
Unknown

10.1.6.1 Does it appear that the system was installed per the manufacturers' design documentation?
Q YES
口 NO
Not Applicable
unknown

10.1.6.2 Is the shuttering/protective system frame directly anchored into the wall around the window?

$\square$ YES $\square$ NO $\square$ Not Applicable $\square$ Unknown

10.1.6.3 If a film protective system is used, does the film cover the entire glazing (exposed glass and portions embedded in the frame)?

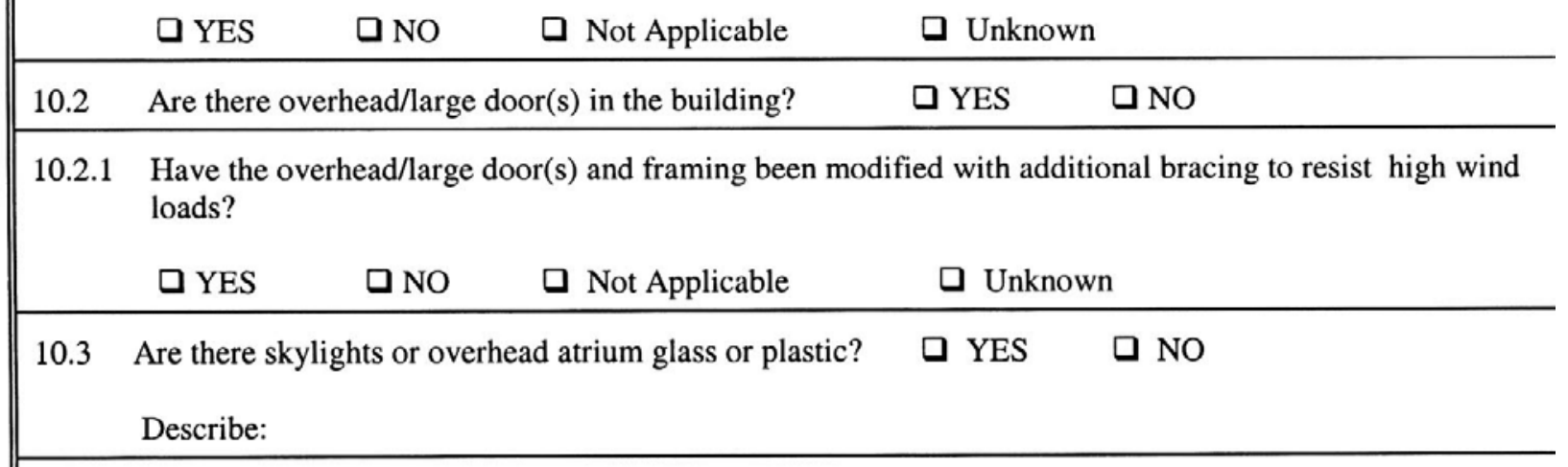

10.4 Comments: 


\section{References}

Bell, R. (1998). "1.4 million residents in N.O. area told: Get out." The Times-Picayune, September 26, p. A17.

Emergency Operations Plan. (1996). Louisiana Office of Emergency Preparedness.

Guidelines for hurricane evacuation shelter selection. (1992). American Red Cross, Arc4496.

Mass care: Preparedness and operations. (1987). American Red Cross, Arc3031.

University of Florida. (1997). School of Building Construction and Division of Emergency Management. Hurricane Evacuation Shelter Selection Guidelines. Department of Community Affairs, Tallahassee, Fla. 